\title{
The conversion technology of fly ash into zeolites
}

\author{
Magdalena Wdowin • Małgorzata Franus • \\ Rafał Panek $\cdot$ Lidia Badura $\cdot$ Wojciech Franus
}

Received: 25 October 2013/Accepted: 20 January 2014/Published online: 31 January 2014

(C) The Author(s) 2014. This article is published with open access at Springerlink.com

\begin{abstract}
This paper presents a sub-pilot scale process of synthesis of Na-P1 zeolite from the coal fly ash. After establishing the appropriate synthesis conditions $(20 \mathrm{~kg}$ of fly ash, $12 \mathrm{~kg}$ of $\mathrm{NaOH}, 90 \mathrm{dm}^{3}$ of water, the reaction temperature: $80{ }^{\circ} \mathrm{C}$ and reaction time: $36 \mathrm{~h}$ ), the highpurity $(81 \mathrm{wt} \%) \mathrm{Na}-\mathrm{P} 1$ zeolite product was obtained. Its chemical, mineralogical, and textural properties were determined (by means of XRD, XRF, SEM-EDS and ASAP 2020). The synthesized material has a specific BET surface area $\left(88 \mathrm{~m}^{2} / \mathrm{g}\right) \mathrm{c}$.a. six times higher than the fly ash from which it has been derived $\left(15 \mathrm{~m}^{2} / \mathrm{g}\right)$. The pore-size distribution indicates a mesoporous character of the obtained zeolite, with the following pores size contents: micropores $(2.76 \%)$, mesopores $(61.81 \%)$, and macropores $(35.43 \%)$. The presented technological/production line is fully automated and allows to regulate the conditions of the synthesis process, therefore different types of zeolite materials (including: Na-X, Linde-A, and Na-P1) can be obtained using the same equipment.
\end{abstract}

Keywords Technological line $\cdot$ Fly ash $\cdot$ Na-P1 . Synthesis reaction

\footnotetext{
M. Wdowin ( $\square)$

Mineral and Energy Economy Research Institute of the Polish Academy of Sciences, Wybickiego 7, 31-261 Kraków, Poland e-mail: wdowin@gmail.com
}

M. Franus · R. Panek · L. Badura · W. Franus Lublin University of Technology, Nadbystrzycka 38D, 20-618 Lublin, Poland

\section{Introduction}

Zeolites are micro and mesoporous hydrated aluminosilicates of alkali elements, alkaline earth metals, or other cations. Their structure is built up with a framework of tetrahedral molecules, linked with shared oxygen atoms (Merrikhpour and Jalali 2013). Their crystal structure contains numerous channels and chambers of different sizes (in the order of several angstroms) giving them a range of unique ion-exchange, sorption, molecular-sieve, and catalytic properties (Derkowski et al. 2006, 2007). Due to their unique properties, zeolites have found application in many branches of industry: in agriculture (e.g. Polat et al. 2004), medicine (Andronikashvili et al. 2009), chemical technology [i.e. desulfurization of fuel (Muzic et al. 2012) or oil refining (Zhu et al. 2013)], and environment engineering [i.e. to remove of ammonium ions (Franus and Wdowin 2010; Liu et al. 2012) or heavy metals from waters and waste water (Merrikhpour and Jalali 2013; Wang et al. 2009) or separation/adsorption of gases such as $\mathrm{CO}_{2}$ (Walton et al. 2006; Wdowin et al. 2012), $\mathrm{SO}_{2}$ (Yi et al. 2012) or mercury (Morency et al. 2002), and removal of radionuclides from the mine waters (Chałupnik et al. 2013)].

Natural zeolites are represented by more than 100 mineral forms. They are formed in different geological environments (magmatic, sedimentary, and metamorphic). However, only some of them (among others clinoptilolite, mordenite, philipsite, or chabazite) occur in a formation that can be viable for extraction and processing.

At the end of the last century, the technologies of manufacturing synthetic zeolites started to develop with great intensity. They allow us to obtain zeolites with specific structure parameters, which qualify them for particular industrial applications (including as selective molecular 
sieves). Synthetic zeolites can be produced from numerous resources such as:

- Clay minerals: bentonite (Faghihian and Godazandeha 2009), kaolin (Ismael 2010), illite-smectite (Baccouche et al. 1998),

- Minerals from the group of silica: perlite (Christidis and Papantoni 2008; Pichór et al. 2014), diatomite (Höllen et al. 2012),

- Waste materials such as coal fly ash (Derkowski et al. 2006, 2007; Izidoro et al. 2013; Querol et al. 2002; Steenbruggen and Hollman 1998; Yadav and Manyar 2005).

As natural zeolites generally require costly modifications in order to be applied in industry, the synthetic zeolites are considered to be more desirable mineral resource for industrial applications. However, as the process of zeolite synthesis is also associated with substantial costs inexpensive mineral or waste materials, such as fly ash, should be used as a substrate for the synthesis reaction (Franus and Wdowin 2011).

The possibility of using hard coal fly ash (conventional and fluidised bed combustion), as well as brown coal for the synthesis of zeolite materials has been intensively investigated in the recent years. Depending on synthesis condition, it is possible to obtain various types of zeolitic materials.

Literature and data show that by using appropriate synthesis conditions, coal fly ash can be converted into different zeolite structures such as analcime (Adamczyk and Bialecka 2005; Querol et al. 1997; Wang et al. 2003), chabazite (Wang et al. 2003), cancrinite, gmelinite, Na-P1 (Adamczyk and Białecka 2005; Hollman et al. 1999; Wang et al. 2003), ZSM-5 (Mohamed et al. 2008), ZSM-28 (Wang et al. 1998), Na-X (Derkowski et al. 2006, 2007; Franus 2012; Querol et al. 1997; Tanaka et al. 2002), Na-Y (Ojha et al. 2004), philipsite (Querol et al. 1997), and sodalite (Musyoka et al. 2011).

Though many laboratory researches have been devoted to the conversion of fly ash into zeolites, there is little research concerning the implementation of this process at a pilot-plant or industrial scale (Kikuchi 1999; Mainganye et al. 2013; Moutsatsou et al. 2008; Querol et al. 2001). However, those scaled up processes were either very simplified (Mainganye et al. 2013; Moutsatsou et al. 2008) or over complicated (Kikuchi 1999). In addition, the weight percent of pure-zeolite phase in the synthesized materials was relatively low (30-40 wt\%) (Querol et al. 2001).

Following successful conversion of class F coal fly ash into synthetic zeolites (on the laboratory scale), a prototype of a technological line for this kind of process has been constructed. After numerous tests, the process line has been optimized and its current state is described in this paper.

\section{Material}

F-class fly ash from the combustion of coal at the Rybnik power plant in Poland was used as a substrate for the synthesis reaction of the zeolite material. The chemical composition of this fly ash consists predominately of $\mathrm{SiO}_{2}$ (52\%), $\mathrm{Al}_{2} \mathrm{O}_{3}(32 \%)$, and $\mathrm{Fe}_{2} \mathrm{O}_{3}(5 \%)$, respectively. The rest of the chemical components occurs in insignificant amounts (Franus 2012).

The mineral composition is dominated by spherical forms of aluminosilicate glass $(68 \%)$ and mullite $(22 \%)$. In addition, quartz and iron oxides (in the form of magnetite and hematite) have been observed on the surface of the aluminosilicate spheres (Fig. 1).

\section{Methods}

The chemical and mineral composition of substrates and products were determined by using a scanning electron microscope SEM-EDS and X-ray method, respectively. Textural characterization of the materials was carried out with a low-temperature nitrogen adsorption-desorption method.

The mineral composition was determined via powder X-ray diffraction (XRD) method using a Philips X'pert APD diffractometer (with a PW 3020 goniometer), $\mathrm{Cu}$ lamp, and a graphite monochromator. The analysis was performed within the angle range of 5-65 20. Philips X'Pert Highscore software was used to process the diffraction data. The identification of mineral phases was based on the PDF-2 release 2010 database formalized by the ICDD.

The morphological forms and the chemical composition of the main mineral components were determined by the means of a scanning electron microscope (SEM) FEI Quanta 250 FEG equipped with a system of chemical composition analysis based on energy dispersive X-rayEDS of EDAX company.

The chemical composition of the fly ashes used for the synthesis reactions was determined by XRF method with the use of a Philips spectrometer PW 1404. An X-ray tube equipped with dual $\mathrm{Cr}-\mathrm{Au}$ anode with a maximum power of $3 \mathrm{~kW}$ was the excitation source.

Nitrogen adsorption-desorption measurements were carried out at $77 \mathrm{~K}$ using an ASAP 2020 volumetric adsorption analyzer (Micromeritics). The BET specific surface areas $\left(\mathrm{S}_{\mathrm{BET}}\right)$ of the investigated samples were evaluated using the standard Brunauer-Emmett-Teller (BET) method for nitrogen adsorption data in the range of relative pressure $p / p_{0}$ from 0.06 to 0.3 . The total pore volumes were estimated from single-point adsorption at a relative pressure of 0.98 . The pore-size distributions were 

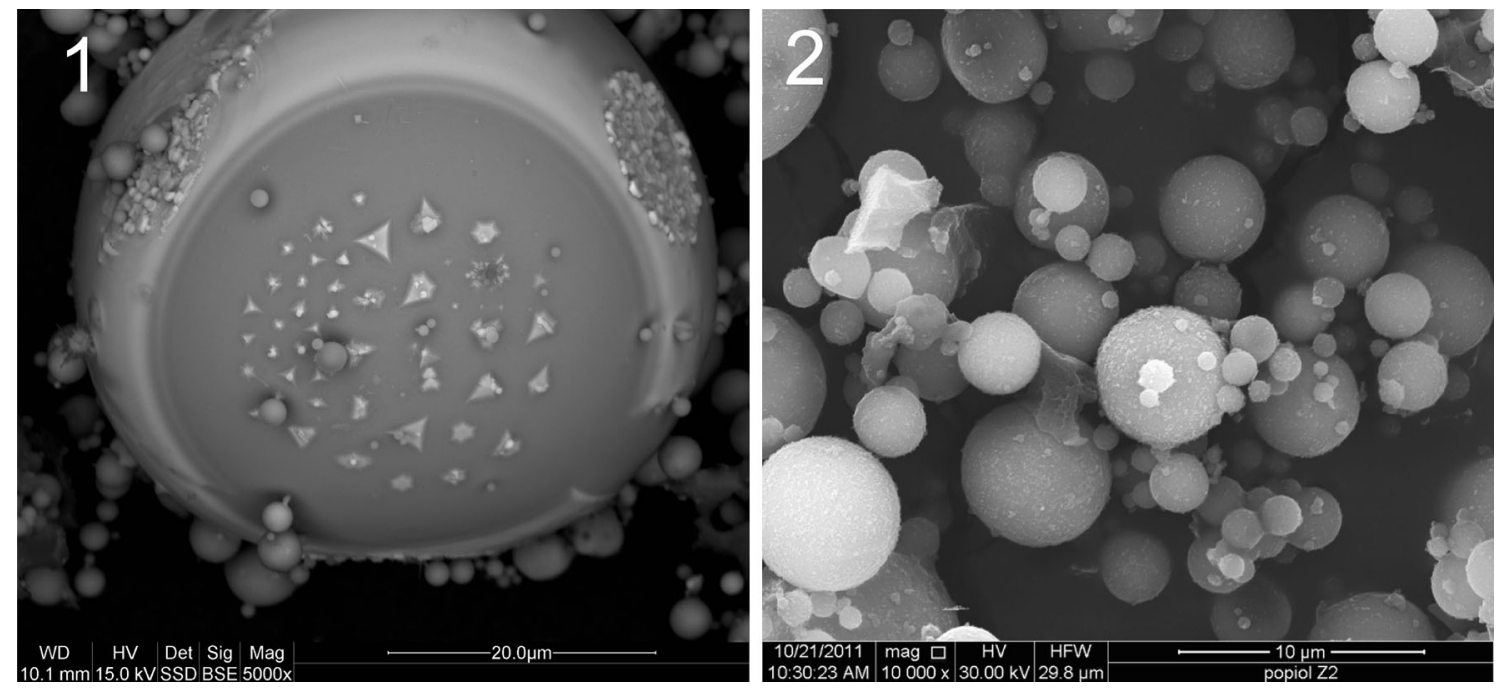

Fig. 1 SEM images of fly ash used for the synthesis. 1 Magnification $5000 \times, 2$ magnification $10000 \times$

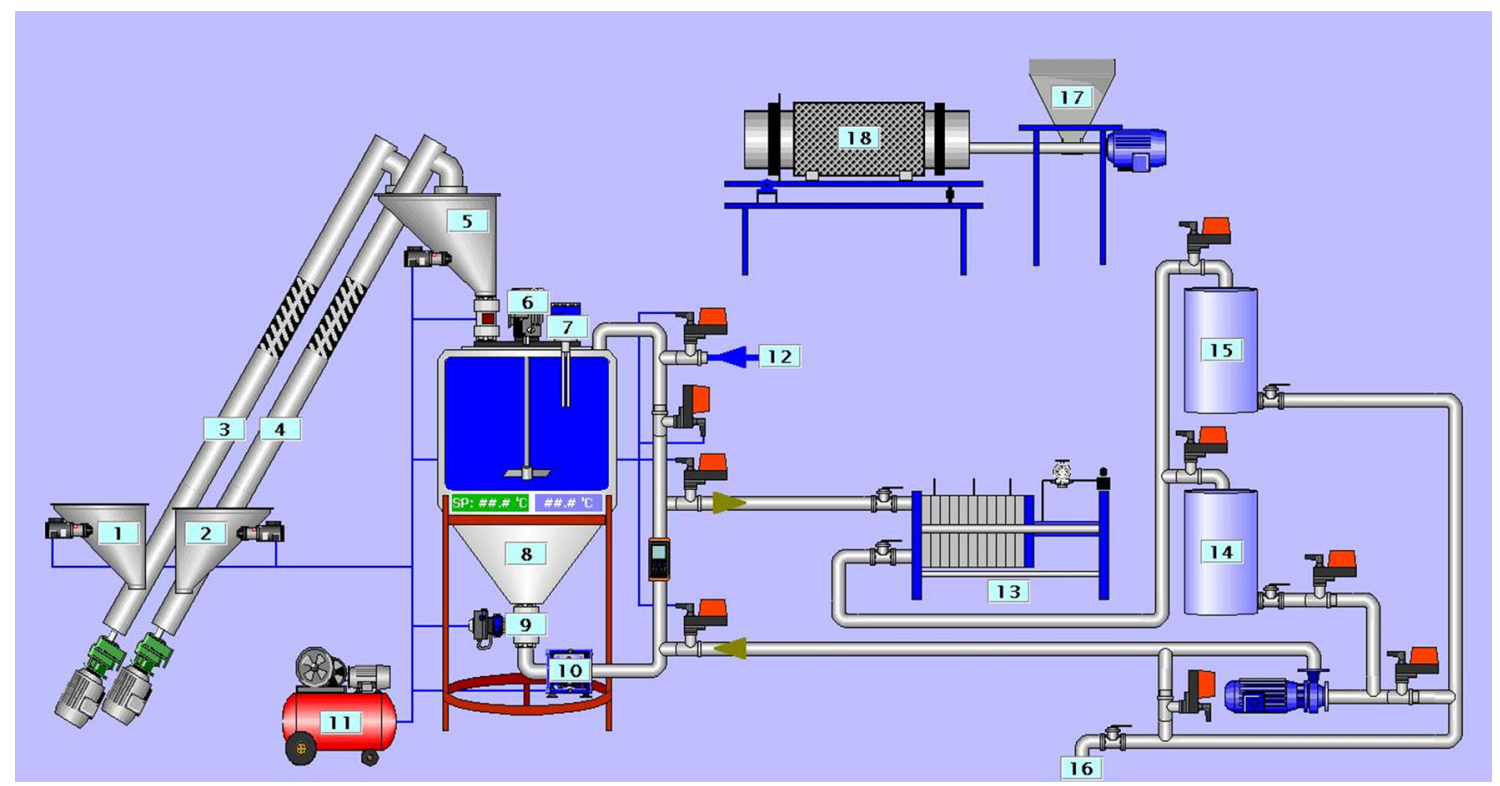

Fig. 2 Technological scheme of the prototype line for the synthesis of zeolites: $1 \mathrm{NaOH}$ storage tank with the vibrator, 2 fly ash storage tank with the vibrator, 3 screw conveyor transporting $\mathrm{NaOH}, 4$ screw conveyor transporting fly ash, 5 weighting tank suspended on threestrain gauge weight sensors with the vibrator, 6 mechanical stirrer, 7 heater with the control system of the reactants level and reaction

obtained from the desorption branch of the isotherm using the Barrett-Joyner-Halenda (BJH) procedure.

\section{Technological line for the conversion of fly ashes into zeolites}

Figure 2 presents the photography of a device for the production of zeolites at a pilot-plant scale. The synthesis process temperature, 8 reaction vessel, 9 pneumatic membrane valve, 10 membrane pump, 11 compressor, 12 water supply with the control volume by means of flowmeter, 13 hydraulic press, $14 \mathrm{NaOH}$ aqueous solution of the synthesis reaction, 15 water solution from flushing of zeolite material in the press, 16 waste for disposal, 17 feed to the calciner, 18 calciner

can be divided into four stages: a stage of the reactor loading, a reaction stage, a stage for the separation of reaction products, and a stage for final processing of the obtained material.

The stage for the reactor loading takes place in two storage tanks, where granulated $\mathrm{NaOH}$ and fly ash are stored. These tanks are connected with a weight tank by means of two worm gears; the purpose of each worm gear is the transport of fly ash and sodium hydroxide granules from the storage tank to the weight tank. 
The tank is made of stainless steel. It has the shape of a converse cone-head ended by a roller. In order to avoid excessive dusting of the room, the tank is closed by a cap. To provide suitable amount of substrates for the synthesis reaction, the tank is mounted on three-strain gauge weight sensors. In order to improve the drop of substrates $(\mathrm{NaOH}$, fly ash) to the synthesis reaction tank, the worm gears and the weight tank are equipped with pneumatic piston vibrators.

The conversion process of fly ash into zeolites takes place in the reaction tank which is the main component of the described line. The total volume of the tank is $130 \mathrm{dm}^{3}$ (working volume is $100 \mathrm{dm}^{3}$ ). The tank is equipped with a system of three heaters ( $2 \mathrm{~kW}$ each), a probe for controlling the reaction temperature, and the level of tank filling probe, and a stirrer that is sequentially switched on and is responsible for the homogenization of the material and prevents the aggregation of the material during the reaction process. A pneumatic membrane that pumps the zeolite material during and after reaction is installed at the tank outlet.

The separation of the products block consists of a filter press and two tanks in which the post-reaction aqueous solution of $\mathrm{NaOH}$ as well as materials rinsing solution are stored. The aqueous solution from the first rinsing of the reaction products is directed to the storage tank and then pumped back to the reactor for further synthesis. The solution from rinsing is returned to its original composition and is directed to the next reaction cycle.

The volume of water during loading and the volume of solution after modification process and recycling are controlled by flowmeters.

The final processing stage occurs in a ribbon feeder and a rotary furnace. The rotary furnace is used to dry the zeolite material obtained by filtration of the solution and for its calcination.

The whole process is fully automated and controlled by a computer, and touch screens are located in the cabinets of each technological blocks.

\section{Mineral characterization and textural properties of the obtained zeolite}

By using the designed technological line, a number of zeolite synthesis reactions were carried out. The monomineral zeolite Na-P1 was obtained in the following reaction conditions: $20 \mathrm{~kg}$ of fly ash, $12 \mathrm{~kg} \mathrm{NaOH}, 90 \mathrm{dm}^{3}$ of $\mathrm{H}_{2} \mathrm{O}$, temperature of the process $80{ }^{\circ} \mathrm{C}$, and duration $36 \mathrm{~h}$. Obtained zeolite materials were fully characterized by scanning electron microscopy coupled with energy dispersive spectroscopy (SEM-EDS), powder X-ray diffraction, and nitrogen adsorption-desorption isotherm.

Diffractograms that show the mineral composition of the zeolite material are presented in Fig. 3. The presence of
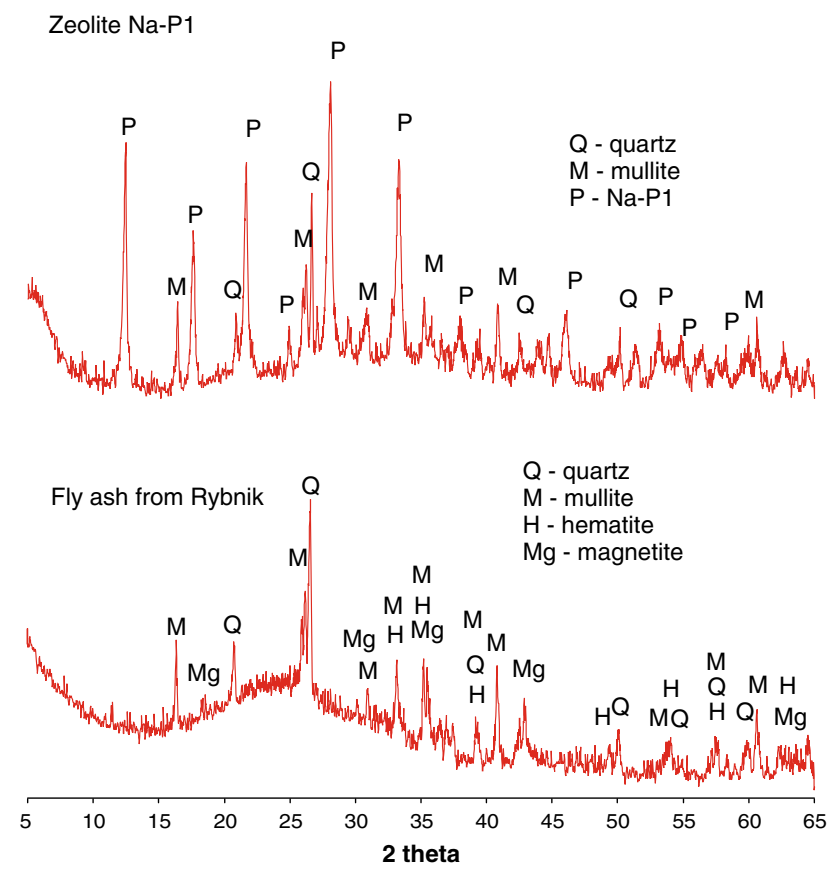

Fig. 3 X-ray diffraction patterns of fly ash and zeolite material. 1 Fly ash EC Rybnik, 2 zeolite material. Clarifications: $P$ Na-P1, $Q$ quartz, $M$ mullite, $H$ hematite, $M g$ magnetite

Na-P1 zeolite phase in the reaction products was determined based on the characteristic interplanar distances $\mathrm{dhkl}=7.10 ; 5.01 ; 4.10 ; 3.18 \AA$. The content of purezeolite phase in the product obtained under given conditions was $81 \%$.

The morphologies of the fly ash used for the synthesis reaction and the obtained zeolite Na-P1 are shown in Fig. 4. Chemical analysis in the micro-area revealed that sodium is the main-exchange cation in the zeolite structure, which balances the charge of aluminosilicate framework. Average ratios of individual cations obtained by EDS are as follows: $\mathrm{Na}+\mathrm{K}+\mathrm{Ca}+\mathrm{Mg} / \mathrm{Si}=0.44 ; \mathrm{Si} / \mathrm{Al}=1.42$.

Textural properties [nitrogen adsorption-desorption isotherms and pore-size distributions (PSD) obtained by BJH method] are presented in Fig. 5.

Fly ash has a low-specific BET surface area $\left(15 \mathrm{~m}^{2} / \mathrm{g}\right)$. Nitrogen adsorption-desorption isotherm for fly ash can be classified as type II isotherm according to the IUPAC classification and is characteristic for macroporous materials with relatively small-specific surface area. In addition, the pore-size distribution indicates a low porosity of fly ash.

Whereas, Na-P1 zeolite has a BET specific surface area of $88 \mathrm{~m}^{2} / \mathrm{g}$, which is almost six times higher with respect to fly ash. A high-specific surface area is preferable for providing large adsorption capacity, so it means that zeolite may be used as adsorbent of many pollutant in such as heavy metals, radionuclides, or some gases etc. Its nitrogen adsorption- 

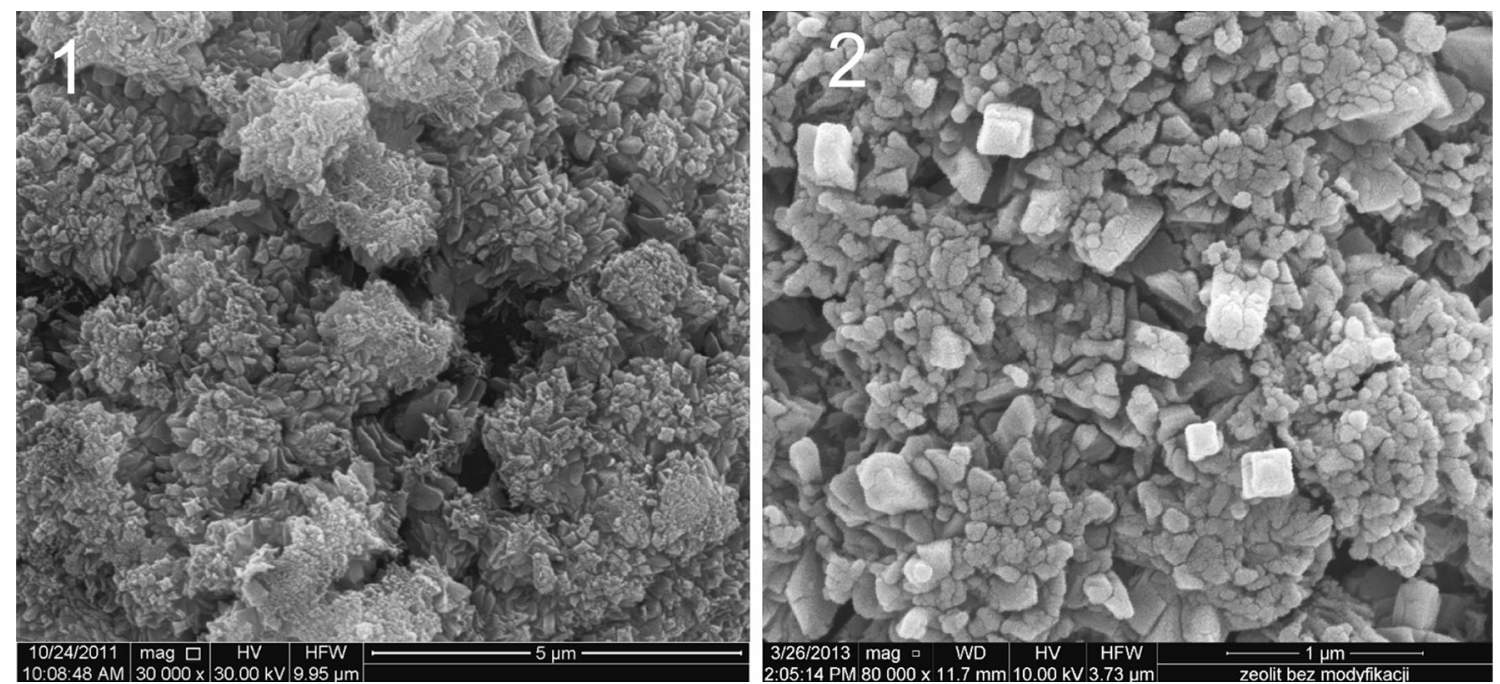

Fig. 4 SEM images of zeolite Na-P1. 1 Magnification $30000 \times, 2$ magnification $80000 \times$
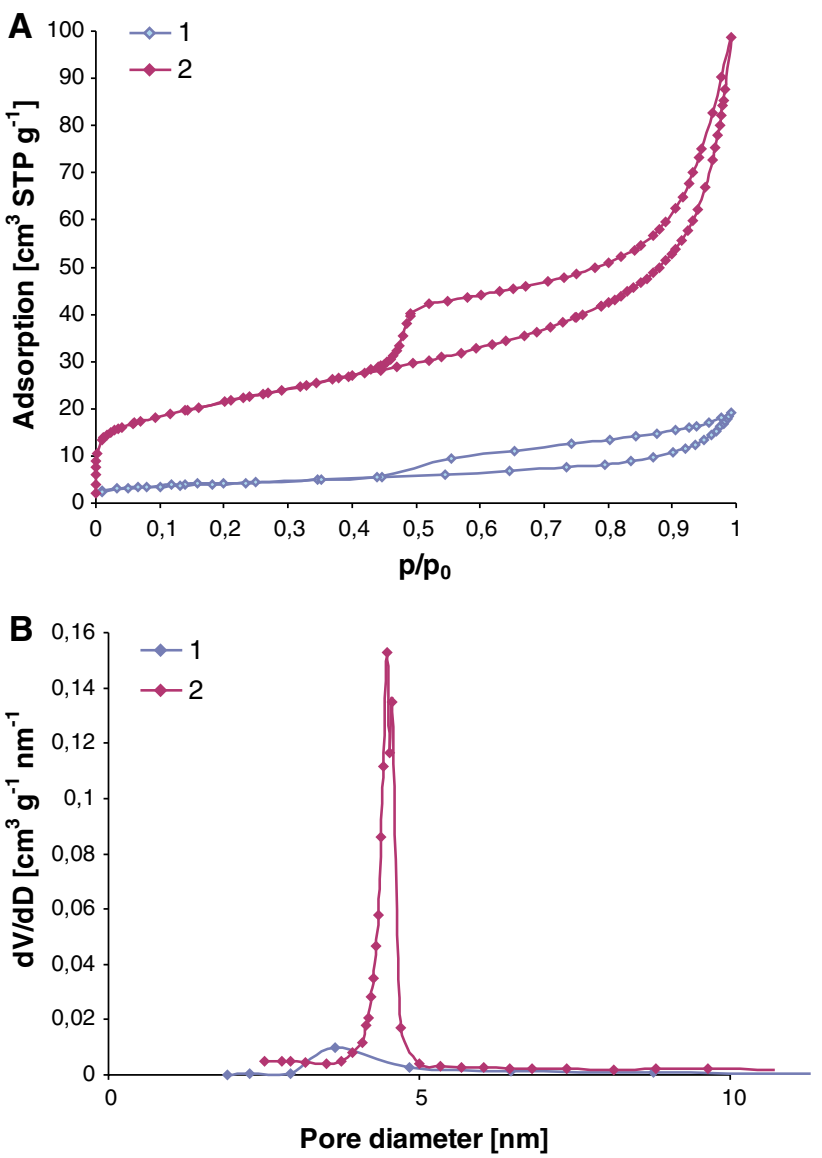

Fig. 5 Textural properties of the materials: 1 fly ash, 2 Na-P1. a Nitrogen adsorption/desorption isotherms, b pore-size distribution

desorption isotherm shape can be classified as IV type (with hysteresis loop) in IUPAC classification which is associated with capillary condensation in mesopores. The shape of the hysteresis by de Boer (1958) indicates the type B, which is related to the presence of "bottle shape" pores. The hysteresis loop is most similar to the H3 type in IUPAC classification, which is characteristic for mesopores in the shape of narrow slits. The pore-size distribution by BJH indicates a mesoporous character of the material, where the contribution of individual pores is as follows: micropores $(2.76 \%)$, mesopores $(61.81 \%)$, and macropores (35.43\%).

\section{Conclusions}

The technological line presented in the paper offers promising and long-term results in the search of new solutions for the utilization of waste materials such as fly ash. This line is fully automated and allows to synthesize the high-purity Na-P1 (zeolite content $81 \mathrm{wt} \%$ ) from the coal fly ash in a very effective and efficient way. The obtained material is mainly mesoporous (c.a. $61 \%$ ) and has approximately six times higher the specific BET surface area than the fly ash from which it has been synthesized. These properties indicate a possibility to use the NaP1 zeolite as an adsorbent for many pollutants, including heavy metals (Wang et al. 2009), radionuclides (Chałupnik et al. 2013), or gases such as $\mathrm{CO}_{2}$ (Walton et al. 2006).

After changing the synthesis conditions, the same line has been successfully used to produce other types of zeolites such as $\mathrm{Na}-\mathrm{X}$ and Linde-A.

In summary, the described technological line has some advantages and originality in comparison to previously described systems (Kikuchi 1999; Mainganye et al. 2013; Moutsatsou et al. 2008; Querol et al. 2001). It has full automation of the systems and the what is important zeolite product of reaction have high-purity average $61 \% \mathrm{wt}$ of 
zeolite. Additional the system enable to changing the condition of reactions simultaneously allowing to obtain various type of zeolite.

Acknowledgments The research was financed by NCBiR as a part of the Applied Research Programme (Program Badan Stosowanych) PBS1/A2/7/2012 and by the National Center For Research and Development Contract no. NCBR/FENCO-NET 1/2013.

Open Access This article is distributed under the terms of the Creative Commons Attribution License which permits any use, distribution, and reproduction in any medium, provided the original author(s) and the source are credited.

\section{References}

Adamczyk Z, Białecka B (2005) Hydrothermal synthesis of zeolites from Polish coal fly ash. Pol J Environ Stud 14(6):713-719

Andronikashvili T, Pagava K, Kurashvili T, Eprikashvili L (2009) Possibility of application of natural zeolites for medicinal purposes. Bull Georgian Natl Acad Sci 3(2):158-167

Baccouche A, Srasra E, El Maaoui M (1998) Preparation of Na-P1 and sodalite octahydrate zeolites from interstratified illitesmectite. Appl Clay Sci 13:255-273

Chałupnik S, Franus W, Wysocka M, Gzyl G (2013) Application of zeolites for radium removal from mine water. Environ Sci Pollut Res 20(11):7900-7906

Christidis GE, Papantoni H (2008) Synthesis of FAU type zeolite Y from natural raw materials: hydrothermal $\mathrm{SiO}_{2}$-sinter and perlite glass. Open Miner J 2:1-5

de Boer JH (1958) In: Everett DH, Stone FS (eds) The structure and properties of porous materials. Butterworth, London, p 68

Derkowski A, Franus W, Beran E, Czímerová A (2006) Properties and potential applications of zeolitic materials produced from fly ash using simple method of synthesis. Powder Technol 166(1):47-54

Derkowski A, Franus W, Waniak-Nowicka H, Czímerová A (2007) Textural properties vs. CEC and EGME retention of $\mathrm{Na}-\mathrm{X}$ zeolite prepared from fly ash at room temperature. Int J Miner Process 82(2):57-68

Faghihian H, Godazandeha N (2009) Synthesis of nano crystalline zeolite Y from bentonite. J Porous Mater 16(3):331-335

Franus W (2012) Characterization of X-type zeolite prepared from coal fly ash. Pol J Environ Stud 21(2):337-343

Franus W, Wdowin M (2010) Removal of ammonium ions by selected natural and synthetic zeolites. Gosp Sur Miner-Miner Res Manag 26(4):133-148

Franus W, Wdowin M (2011) Wykorzystanie popiołów lotnych klasy $\mathrm{F}$ do produkcji materiału zeolitowego na skalę półtechniczną. Polityka Energetyczna 14(2):79-91

Höllen D, Klammer D, Letofsky-Papst I, Dietzel M (2012) Hydrothermal alteration of diatomite for removal of aqueous $\mathrm{Cu} 2+$, $\mathrm{Pb} 2+$ and $\mathrm{Zn} 2+$. J Mater Sci Eng B2(10):523-533

Hollman GG, Steenbruggen G, Janssen-Jurkovicova M (1999) A twostep process for the synthesis of zeolites from coal fly ash. Fuel 78:1225-1230

Ismael IS (2010) Synthesis and characterization of zeolite X obtained from kaolin for adsorption of $\mathrm{Zn}(\mathrm{II})$. Chin $\mathrm{J}$ Geochem 29(2):130-136

Izidoro JC, Fungaro DA, Abbott JE, Wang S (2013) Synthesis of zeolites $\mathrm{X}$ and $\mathrm{A}$ from fly ashes for cadmium and zinc removal from aqueous solutions in single and binary ion systems. Fuel 103:827-834
Kikuchi R (1999) Application of coal ash to environmental improvement. Transformation into zeolite, potassium fertilizer, and FGD absorbent. Resour Conserv Recycl 27:333-346

Liu H, Peng S, Shu L, Chen T, Bao T, Frost RL (2012) Effect of $\mathrm{Fe}_{3} \mathrm{O}_{4}$ addition on removal of ammonium by zeolite NaA. J Colloid Interface Sci 390(1):204-210. doi:10.1016/j.jcis.2012. 09.010

Mainganye D, Ojumu TV, Petrik L (2013) Synthesis of zeolites NaP1 from South African coal fly ash: effect of impeller design and agitation. Materials 6:2074-2089. doi:10.3390/ma6052074

Merrikhpour H, Jalali M (2013) Comparative and competitive adsorption of cadmium, copper, nickel, and lead ions by Iranian natural zeolite. Clean Technol Environ Policy 15:303-316. doi:10.1007/s10098-012-0522-1

Mohamed MM, Zidan FI, Thabet M (2008) Synthesis of ZSM-5 zeolite from rice husk ash: characterization and implications for photocatalytic degradation catalysts. Microporous Mesoporous Mater 108:193-203

Morency JR, Panagiotou T, Senior CL (2002) Zeolite sorbent that effectively removes mercury from flue gases. Filtr Sep 39(7):24-26

Moutsatsou A, Karakasi OK, Koukouzas N, Itskos GS, Vasilatos Ch (2008) WanteEng-2nd international conference on engineering for waste valorisation, Patras, June 2008

Musyoka NM, Petrik LF, Balfour G, Gitari WM, Hums E (2011) Synthesis of hydroxy sodalite from coal fly ash using waste industrial brine solution. $J$ Environ Sci Health A 46(14):1699-1707. doi:10.1080/10934529.2011.623961

Muzic M, Sertic-Bionda K, Adzamic T (2012) Evaluation of commercial adsorbents and their application for desulfurization of model fuel. Clean Technol Environ Policy 14:283-290. doi:10.1007/s10098-011-0399-4

Ojha K, Pradhan NC, Samanta AN (2004) Zeolite from fly ash: synthesis and characterization. Bull Mater Sci 27(6):555-564

Pichór W, Mozgawa W, Król M, Adamczyk A (2014) Synthesis of the zeolites on the lightweight aluminosilicate fillers. Mater Res Bull 49:210-215

Polat E, Karaca M, Demir H, Onus N (2004) Use of natural zeolite (clinoptilolite) in agriculture. J Fruit Ornam Plant Res 12:183-189

Querol X, Plana F, Alastuey A, Lopez-Soler A (1997) Synthesis of Na-zeolites from fly ash. Fuel 76:793-799

Querol X, Umana JC, Plana F, Alastuey A, Lopes-Soler A, Medinaceli A, Valero A, Domingo MJ, Garcia-Rojo E (2001) Synthesis of zeolites from fly ash pilot plant scale. Examples of potential applications. Fuel 80:857-865

Querol X, Moreno N, Umana JC, Alastuey A, Hernandez E, LopezSoler A, Plana F (2002) Synthesis of zeolites from coal fly ash: an overview. Int J Coal Geol 50:413-423

Steenbruggen G, Hollman GG (1998) The synthesis of zeolites from fly ash and the properties of the zeolite products. J Geochem Explor 62:305-309

Tanaka H, Sakai Y, Hino R (2002) Formation of Na-A and -X zeolites from waste solutions in conversion of coal fly ash to zeolites. Mater Res Bull 37:1873-1884

Walton KS, Abney MB, Douglas LM (2006) $\mathrm{CO}_{2}$ adsorption in Y and $\mathrm{X}$ zeolites modified by alkali metal cation exchange. Microporous Mesoporous Mater 91:78-84

Wang HP, Lin KS, Huang YJ, Li MC, Tsaur LK (1998) Synthesis of zeolite ZSM-48 from rice husk ash. J Hazard Mater 58:147-152

Wang Y, Guo Y, Yang Z, Cai H, Querol X (2003) Synthesis of zeolites using fly ash and their application in removing heavy metals from waters. Sci China (Ser D) 46(9):967-976

Wang H, Li J, Sun X, Wang L, Sun X (2009) Evaluation of zeolites synthesized from fly ash as potential adsorbents for wastewater containing heavy metals. J Environ Sci 21:127-136 
Wdowin M, Franus W, Panek R (2012) Preliminary results of usage possibilities of carbonate and zeolitic sorbents in $\mathrm{CO}_{2}$ capture. Fresen Environ Bull 21(12):3726-3734

Yadav GD, Manyar HG (2005) Converting liability into asset: novel mesoporous zeotype from fly ash using silatrane chemistry. Clean Technol Environ Policy 7:162-167

Yi H, Deng H, Tang X, Yu Q, Zhou X, Liu H (2012) Adsorption equilibrium and kinetics for $\mathrm{SO}_{2}, \mathrm{NO}, \mathrm{CO}_{2}$ on zeolites FAU and
LTA. J Hazard Mater 15(203-204):111-117. doi:10.1016/j. jhazmat.2011.11.091

Zhu J, Meng X, Xiao F (2013) Mesoporous zeolites as efficient catalysts for oil refining and natural gas conversion. Front Chem Sci Eng 7(2):233-248 